\title{
Introduction: Jane Austen Travels
}

Jane Austen should stay at home, was the somewhat defeatist conclusion of a 1975 comparison of six translations from around the world. ${ }^{1}$ Some of them were competent, others weak, but they all seemed to struggle with the finer points of Austen's style. Such a purist sentiment is all well and good, and quite understandable. Perhaps there is something untranslatable about all great authors; nuances that can only be found in their own language. ${ }^{2}$

But Jane Austen will not stay at home. She has been travelling to other countries, speaking foreign languages, since her books started to come out. She has spoken French since 1813, German since 1822, Swedish since 1836, Portuguese since 1847 , Danish since 1855 and Norwegian since $1871 .^{3}$ She crossed the Atlantic to Brazil (the 1847 translation) and in American English editions in 1816 and $183^{2-}-33$ (the latter comprised all six novels). ${ }^{4}$ Right after the First World War, she learnt to speak Spanish (1919), Dutch and Finnish (1922). She crossed the world in the opposite direction and learnt foreign sign systems in Japan (1926) ${ }^{5}$ and China (1935). ${ }^{6}$ She travelled to Eastern Europe, and spoke Serbo-Croat (1929) and Czech (1932), Hungarian and Polish (1934). At the same time, she spoke Italian (1932).

The years of the Second World War saw an explosion of interest in Austen's authorship, with thirty-two European translations between 1941 and 1945, the majority of them into the Romance languages - Portuguese, Spanish and Italian. Sometimes two translators worked on the same novel in the same country simultaneously, presumably without knowing of each other's work. ${ }^{7}$

1 Andrew Wright, "Jane Austen Abroad", in Jane Austen: Bicentenary Essays, ed. John Halperin, Cambridge, 1975, 317 .

2 See recent debates on "untranslatability", for instance by Emily Apter or Susan Bassnett, who explains its linguistic and cultural subtypes (Susan Bassnett, Translation Studies, Abingdon and New York, 2014, 40-45).

3 A Timeline of European translations until 2013 is given in the opening of Anthony Mandal and Brian Southam, The Reception of Jane Austen in Europe, London, 2014.

4 For covers and descriptions of these early American editions, see Margaret C. Sullivan, Jane Austen Cover to Cover: 200 Years of Classic Covers, Philadelphia, PA, 2014, 16-17 and 23. The book also includes a number of twentieth- and twenty-first century foreign covers, in addition to its main emphasis on English editions.

5 Hiroshi Ebine, et al., "Jane Austen in Japanese Literature: An Overview", Persuasions On-Line, $30 / 2$.

6 Helong Zhang, “Jane Austen's One Hundred Years in China”, Persuasions, 33/105.

7 This happened with Emma in Italy, Northanger Abbey and Pride and Prejudice in Spain, see Timeline in Mandal and Southam, The Reception of Jane Austen in Europe, xxviii.

(C) MARIE NEDREGOTTEN SøRBø, 2018 | DOI 10.1163/9789004337176_002

This is an open access chapter distributed under the terms of the prevailing CC-BY-NC License 
In Japan, as in many other countries, there was a burst of interest after the war: all of Austen's work was translated into Japanese between 1947 and 1978. Turkey presents a similar case, with five of the novels translated between 1946 and $1972 .{ }^{8}$

Since the war, not a year has gone by without seeing several new Austen translations. While there are (so far) no recorded translations between 1898 and 1910, and only three in the first two decades of the twentieth century, she is now among the most translated of British authors. She has traversed the Mediterranean to Greece (1950) and Israel (1952). She speaks the languages of smaller communities (Icelandic 1956, Catalan and Estonian 1985, Basque 1996, Lithuanian 1997, Latvian 2000, Galician 2005), as well as major world languages (Russian since 1967, Arabic since 1970). She is familiar with oriental tongues like Bengali (1953), Hindi (no date), Sinhalese (1964), not to mention Thai (1950), Persian and Korean (both 1958). These are only examples of her travels, not a complete inventory. More translations will very likely resurface as more research is carried out in this field.

The first five French translations came when she was still writing at her desk in Chawton, and all six novels were translated by 1824, Pride and Prejudice in three versions and Mansfield Park in two. In the other languages that had nineteenth-century translations - German, Portuguese and the three Scandinavian languages - only one or two novels were selected. This has been the rule also in twentieth- and twenty-first-century translations: mostly single novels rather than collected editions. When, for instance, a Norwegian publisher commissioned translations of her novels for a series in the late 199os, they decided to leave out Northanger Abbey. ${ }^{9}$

The first attempt at a collection and the first steps in the process of preservation and eventually canonization of her novels came in 1833, when the publisher Richard Bentley, who had bought all the copyrights, included the six novels in his popular series of "Standard Novels". ${ }^{10}$ For the first time, they appeared with illustrations (frontispiece and title-page), and with some critical material included. Bentley's first Austen title, Sense and Sensibility, incorporates

8 Rana Tekcan, “Jane Austen in Turkey”, Persuasions, 28/2.

9 There are exceptions, like a Serbian Collected Novels edition in 1976-77, a Russian in 1988-89, and a French in 200o. Furthermore, the Japanese have now got a scholarly Collected Works edition (see Ebine, et al., "Jane Austen in Japanese Literature: An Overview") and the Chinese have several (see Zhang, "Jane Austen's One Hundred Years in China", $110)$.

10 Kathryn Sutherland, Jane Austen's Textual Lives: From Aeschylus to Bollywood, Oxford, $2005,1-2$. 
a newly revised and extended "Memoir of Miss Austen" by her brother Henry, based on his "Biographical Notice" for the posthumous 1818 publication of her two last novels. ${ }^{11}$ Here we learn that "Miss Austen immediately declined" an invitation to a literary circle at a nobleman's house where she would have met the celebrated Mme de Stäel when the latter visited England. But there is more.

The new material in 1833 also includes three critical assessments. What appears to be an article from a "critical journal of the highest reputation" (xi) turns out to be extracts from two critics. The very last paragraph is by Richard Whately, often credited as the first discerning Austen critic with his 1821 article (for instance by Brian Southam). ${ }^{12}$ But the longest passage, and the most pertinent observations, are from Maria Jewsbury's 1831 article (she is not among the critics included in Southam). ${ }^{13}$ Hers is a perceptive description of Austen's lack of romantic incidents, here called "surprises of a grand nature" (xii), her everydayness ("the mind is never taken off the level surface of life" xii), her characters ("The secret is, Miss Austen was a thorough mistress in the knowledge of human character", xii). ${ }^{4}$

In addition to these two critical voices, the editor himself adds a page of commentary, saying that Austen has been an inspiration for other authors, also male ones, praising her for the way her portraits turn lead into gold, and ending with the same conclusion Virginia Woolf drew a century later: "it would be difficult to detect the secret of the process" $(\mathrm{xv}) .{ }^{15}$

11 David Gilson outlines the textual history of this 1833 "Memoir" and describes the discovery that Henry Austen had quoted Jewsbury as well as Whately in two short pieces (David Gilson, "Henry Austen's 'Memoir of Miss Austen", and "Jane Austen and the Athenaeum Again", Persuasions 19, 1997). There is more information on Bentley's editions in David Gilson, A Bibliography of Jane Austen, Winchester and New Castle, DE, 1997, 209-34.

12 Jane Austen: The Critical Heritage, 2 vols, ed. B.C. Southam, London, 1968, I, 19, 95.

13 The anonymous article is called "Literary Women. No II. Jane Austen" and was published in the Athenaeum. We owe the identification of the author to Joanne Wilkes and before her Monica Fryckstedt (see Joanne Wilkes, “Without Impropriety': Maria Jane Jewsbury on Jane Austen", Persuasions, 13). There is a further discussion of the article in Joanne Wilkes, Women Reviewing Women in Nineteenth-Century Britain: The Critical Reception of Jane Austen, Charlotte Brontë and George Eliot, Farnham, 2010, 31-36.

14 The passage is sometimes ascribed to Richard Whately, notably by George Henry Lewes, attributing them to "the present Archbishop of Dublin", since he is the author of the last paragraph of the extracts. This misattribution is then spread whenever Lewes' piece is reprinted, for instance in Ian Littlewood,Jane Austen: Critical Assessments, Robertsbridge, 1998,345 .

15 The page references are to the first edition: Jane Austen, Sense and Sensibility, London, 1833. Holding Chawton House Library's copy of Sense and Sensibility from 1833, or Bodleian Library's Pride and Prejudice from 1813, adds a new dimension to Austen's 
Bentley reissued the six novels in 1870 in his Favourite Novels series, and finally in 1882 as a proper collected edition: the Steventon Edition. This included additional material: Austen's nephew James Edward Austen-Leigh had published a book-length Memoir of Jane Austen in 1869, with a second edition with newly discovered material the year after, and this was included in The Steventon Edition. So was the first collection of Austen's letters, by her grandnephew Lord Brabourne in 1884. The new interest in Austen's life and work is evident, and it is sometimes difficult to decide which came first, the interest or the Memoir. Austen-Leigh's book was both the cause and effect of this interest. He had to be persuaded to write the book, which is in itself evidence of a growing curiosity about Austen in the years before 1870 . Nevertheless, the Memoir and the Letters took this interest to new heights at the end of the century.

Between Bentley's editions, the market of readers of English abroad was served by Austen's inclusion in the Tauchnitz Collection of British Authors (1864-77) published in Germany. The Tauchnitz series played a vital role in making British literature known in other countries. Their books are found in libraries across Europe. ${ }^{16}$ The selection of Jane Austen for the series clearly means that she was seen as belonging among the classic English authors.

As far as collected editions are concerned, the century finishes with a flourish. The 1894-97 Macmillan edition as well as the two different ten-volume editions by J.M. Dent in 1892 and 1898 are richly illustrated and handsomely bound, the last one of them also in colour. Charles E. Brock did the Macmillan Pride and Prejudice and then together with his brother Henry the Dent 1898 series, while Hugh Thomson did the rest of the Macmillan series. They all went for a certain authenticity of style, in depicting Regency fashions and interiors rather than Victorian ones.

The best example of the turn of the century preoccupation with Austen's work is perhaps Thomson's astoundingly beautiful 1894 edition of Pride and

deliberate miniatures. The books are very small and handy, and in this sense really were miniatures, especially compared to the novels of contemporaries like Frances Burney or Anna Maria Porter. As they also were in their narrative characteristics; Austen has much more disciplined and uniform narratives. She discarded the ramblings of her predecessors, their associations and asides and expositions of more or less related matter. Moreover, Austen's selection of setting and characters is extremely limited compared to, for instance, Porter's novels.

16 For more information on Bernhard Tauchnitz' editions, see Thomas Keiderling, "Leipzig als Vermittlungs- und Produktionszentrum englischsprachiger Literatur zwischen 1815 und 1914", in Beiträge zur Rezeption der britischen und irischen Literatur des 19. Jahrhunderts im deutschsprachigen Raum, ed. Norbert Bachleitner, Amsterdam and Atlanta GA, 2000, $31 \mathrm{ff}$. 
Prejudice for George Allen, for good reasons known as The Peacock Edition of the novel. While the Macmillan and Dent editions of the same novel have 40 and 12 illustrations, respectively, the Peacock Edition has 16o. The cover is entirely covered in the guilt tail-plumes of a peacock, the bird itself is seen on a plinth beside the title, also in gilded letters - PRIDE and PREJUDICE by Jane Austen Illustrated by Hugh Thomson - significantly, the name of the artist is almost as big as the author's. The first chapter starts with the peacock spreading his tail across half the first page. ${ }^{17}$ All first letters of chapters are embellished as in a medieval illuminated manuscript, often with a comic twist, with little figures or faces in them. The many illustrations of scenes from the novel extend to scenes only implied in the narration, for instance Sir Lucas bowing to the King. The whole project demonstrates the late Victorian interest in Austen as a national heirloom, presented for family reading. It is a warm embrace, and some critics have seen it as a crushing one, obscuring her own art, but in the history of her reception it is an early example of Austen adapted into a new cultural and aesthetic horizon. This is what will happen again and again, also in translations.

The next landmark was the first scholarly annotated edition of her work. It was published by Clarendon Press in 1923, and soon taken over by Oxford University Press. The editor was an Oxford scholar, R.W. Chapman, in co-operation with his wife, Katherine Metcalfe, ${ }^{18}$ also an Oxford tutor before their marriage. These facts are all signs of Austen's new academic status in the early twentieth century. In fact, Austen was the first English author to get such an edition, marking the burgeoning discipline of English studies in academia. ${ }^{19}$

The nineteenth-century reception was not only a formal one. In the same way as in later reception, some of Austen's novels were also published in cheap editions. The first seems to have been the 1849 Routledge Railway library series (Pride and Prejudice and Sense and Sensibility), and later the Routledge Sixpenny Novels (Sense and Sensibility in 1884, and Mansfield Park in 1885). Even in the nineteenth century, then, Austen could be bought with cover illustrations designed to tempt the popular market. Also, at the end of the century, abridged editions, dramatic adaptations and schoolbook versions started to appear. $^{20}$

17 The 1894 copy of Pride and Prejudice described here belongs to Chawton House Library.

18 Metcalfe edited Pride and Prejudice already in 1912, and Northanger Abbey in 1923.

19 See Sutherland, Textual Lives, 26.

20 See ibid., 4-5, which also includes an example of a Railway library cover illustration. More examples are found in Sullivan, Jane Austen Cover to Cover: 200 Years of Classic Covers, $24-25$. 
Two hundred years have passed since Austen lived and wrote her six completed novels, ${ }^{21}$ but her reception in these two centuries is strikingly different. To modern readers she is one of the most famous names of literary history. It is a dual popularity: for the high-brow market she is placed alongside Shakespeare, Plato and Euripides, ${ }^{22}$ while for the popular market, she is represented by the faces of famous actors, like Colin Firth or Keira Knightley. It is almost inconceivable for modern readers to grasp her comparative insignificance in much of the nineteenth century, up until 1870, at home, but not least abroad.

Contemporary sources, however, bear witness to it. When the British chaplain in Oslo in 1862, M.R. Barnard, wanted to teach his Norwegian pupils about the best authors of English literature, he mentioned around 230 names, but not Jane Austen. Surely, his general enthusiasm would have encompassed her had he known of her. ${ }^{23}$ She is also missing from other Norwegian textbooks and overviews of the century. ${ }^{24}$

One of Barnard's Norwegian colleagues, however, was better informed. Erik Barth Horn was equally enthusiastic about British literature, and wrote a lengthy article a few years before, where he presented "sixteen English Authoresses". Here, "Miss Austen" is briefly mentioned, but is clearly the least known and least appreciated of them all. He warns us not to confuse her with the translator, Mrs Sarah Austin. Still, he says that Miss Austen is found on young people's bookshelves. We get the impression that she is old-fashioned, but still read. ${ }^{25}$

21 Austen's life span was 1775-1817, and her novels, although composed over a much longer period, were published between 1811 and 1817/18.

22 In the Norwegian publisher Aschehoug's marketing of the series of translations of the late 1990 .

23 M.R. Barnard, Sketches of Eminent English Authors, with Extracts from Their Works, Adapted for Use in Schools, and for Advanced Pupils in the English Language, Christiania, [Oslo] 1862.

24 A. Autenrieth, The English Reader: A Selection of Prose and Poetry from the Best British Authors: For the Use of Schools and Private Tuition, Christiania, [Oslo] 1844; Jakob Løkke, Engelske forfattere $i$ udvalg: Med biografiske indledninger og oplysende anmæerkninger, Copenhagen, 1875; J.F. Bendeke, Kort oversigt over den engelske literatur, Trondheim, 1879; Immanuel Ross, Om den engelske Romans og Novelles Udvikling fra Middelalderen til Nutiden, tildels belyst ved Citater, Bergen, 1880.

25 Erik F.B. Horn, "Engelske forfatterinder", Illustreret Nyhedsblad, Christiania, 1858. vII, 134. The article was unsigned. We find confirmation of his claim that Jane Austen was still read in an 1856 Norwegian rental library record of the 1855 Danish translation of Sense and Sensibility. In the same decade, she is also found in the catalogues of the distinguished Athenceum reading society for men in Christiania (Oslo). 
This is rather in keeping with the impression we get from her reception in Britain, and other countries. Although she had some positive responses in the early years (Scott, Whately, Jewsbury), and although the mid-to-late century connoisseurs claimed they had always appreciated her (G.H. Lewes, Julia Kavanagh, Anne Thackeray Ritchie, Margaret Oliphant and Mary Augusta Ward), Austen's name was not a famous one before the first biography of 1870 . One reason is that her name was never printed in her books in her lifetime. They were published as "By a Lady", or "By the author of...."26 It was perhaps modesty, but also convention - even a male novelist like Walter Scott published anonymously. ${ }^{27}$ Significantly though, she does not hide her gender, which, in fact, is in keeping with her literary context, since most novels in the early century were by female authors. ${ }^{28}$

Although her brother Henry revealed her identity already in $1817 / 18$, in his "Biographical Notice" for Northanger Abbey and Persuasion, some of the translations continued to be published without Austen's name. The very first French translations in 1813,1815 and 1816 were, naturally, anonymous since she was still protecting her anonymity at the time. Her name was exposed in two French translations in 1821 and 1824, which included Henry's piece. ${ }^{29}$ Her 1821 translator, Isabelle de Montolieu, also added her own presentation of Jane Austen, whose identity she had discovered since she first translated her in 1815 .

In spite of this discovery, an 1828 new edition of the 1815 Raison et Sensibilité could at first glance pass for a novel "Par Mme La Baronne Isabelle de Montolieu", whose name is centrally placed on the page, while Jane Austen's name is nowhere to be seen. The only amendment between the two editions is the addition of Montolieu's aristocratic title. Clearly, they saw no reason to

26 When comparing early editions, we notice that some other ladies, for instance Ann Radcliffe and Anna Maria Porter, signed their books, and the anonymous Frances Burney later partly revealed her authorship in forewords. A telling illustration is found in Chapman's third edition of Northanger Abbey and Persuasion from 1933, where he includes a facsimile of the 1794 title page of Radcliffe's Udolpho. This presents the author's name in large print in the middle of the page, in stark contrast to Austen's title pages for a long time afterwards (Jane Austen, Northanger Abbey and Persuasion, Oxford, 1969, 309).

27 For an account of the convention, see John Mullan, Anonymity: A Secret History of English Literature, London, 2007.

28 This is true also of the preceding fifteen years, see the tables in Anthony Mandal, Jane Austen and the Popular Novel: The Determined Author, Basingstoke, 2007, 13, 27.

29 Isabelle Bour, “The Reception of Jane Austen's Novels in France and Switzerland: The Early Years 1813-1828", in The Reception of Jane Austen in Europe, eds Brian Southam and Anthony Mandal, London, 2007, 27, 30. 
add the author's name while preparing the new edition..$^{30}$ Similarly, in 1822, the young translator Mlle Éloïse Perks at least gets her name indicated on the title page, as "Par Mlle É...***", which Austen does not. The 1816 translator, Henri Vilmain, also had his name on partial display as "Par M. Henri $\mathrm{V}^{* * * * * *} \mathrm{~N}^{31}$

Jane Austen's name may have been revealed to the world in 1818 and 1821, but it created no sensation, and was still often neglected, even in her own works. Although she was named in German in 1822, she was anonymous in 1830; although named in Denmark in 1855, she was anonymous in Sweden in 1857 , as she had been in 1836 . When she is named, it is sometimes in a "domesticated" version, amended to fit the receiving language. In 1824, she appears to be a French writer: Jeanne Austen. In 1822, she is seemingly German: Johanna Austen.

In Norway, however, there is no question of anonymity when the $1871-72$ translation appears. As in Denmark sixteen years earlier, she keeps her English name. ${ }^{32}$ This is exactly the time of the new burst of interest in Austen in the wake of the publication of the new Memoir (see next chapter). Of nineteen nineteenth-century translations, eleven were anonymous, six of them after Austen's name had been made public. ${ }^{33}$

Jane Austen has had one century of insignificance and one of adoration. The immense popularity of the Austen film and television productions of the mid-199os and since has evidently boosted her reputation further. In European reception, every post-war decade saw a decent number of translations (highest in the 1940 s and 1980 s with $55^{-56}$, and lowest in the 1970 , with 35 ). In comparison, the 199os produced 97 European translations. The years between 2000 and 2013 had 151 more. This is before we have even started to account for the rest of the world.

Some countries launch new editions of her work at this time, for instance the Turkish series by a Shakespeare translator since $2006,{ }^{34}$ three different Chinese collected work series in 1997 and 1999, ${ }^{35}$ or, indeed, the Norwegian Aschehoug-editions between 1996 and 2003. Along with modern fame goes

30 Compare the two titles pages of 1915 and 1928 in Gilson, A Bibliography of Jane Austen, 156, 159 .

31 See title pages ibid., 143, 150.

32 She also keeps her English name in Montolieu's 1821 translation. For the Danish translation, see facsimile in ibid., 139 .

33 Some Spanish translations were, surprisingly, still anonymous in the twentieth century.

34 Tekcan, "Jane Austen in Turkey".

35 Zhang, "Jane Austen's One Hundred Years in China”, 110. 
popularity in translation: she seems to be one of the most translated of British authors around the world.

Compared to Austen's nineteen nineteenth-century translations (sixteen of them of full novels), ${ }^{36}$ the twenty-first century has had seventeen different Japanese translations in circulation in one particular year (2010), six of them of Pride and Prejudice. ${ }^{37}$

It is useless trying to give an exact number of Austen translations around the world, as any figure calculated and written down in this current book will be outdated before the book even goes to print. Besides, for many countries the number is unknown. Some estimates can, however, be attempted. While David Gilson documents 249 items worldwide in his seminal 1982 bibliography, ${ }^{38}$ this figure is more than doubled in the listings found in the most recent edition of The Reception of Jane Austen in Europe, even if this excludes the rest of the world. ${ }^{39}$ The two centuries from 1813 to 2013 here yield 517 translated titles. If we add Gilson's 36 Asian items to this European list, this means 553 translations.

This does not include anything that has appeared after 2013, and it includes only a few Japanese, Chinese, Turkish or other non-European translations. Moreover, there are uncertainties that hinder any attempts at reaching a total figure. The available studies of non-European reception do not offer complete numbers, and for many languages, no such study has been made.

The glimpses we do get are revealing. Helong Zhang's very valuable overview of Chinese reception mentions around thirty-five translations that have appeared since the two different Pride and Prejudice in 1935, but makes no attempt at completeness. The reason becomes clear when he informs us that "Amazingly, there have been more than fifty Chinese versions of Pride and Prejudice, and at least ten of Sense and Sensibility". ${ }^{40}$ If we assume that

36 The nineteenth-century translated editions are scarce today. The early French translations had small print runs and survive in few copies, and the same is true of the Scandinavian ones. There are only three copies of the 1855 Danish Sense and Sensibility in Denmark; the Swedish 1836 Persuasion is found only in Stockholm, and the 1857 Emma in six copies across the country. They seem to have been little used in their own countries. This impression is confirmed in the respective national chapters by Isabelle Bour, Peter Mortensen, Git Claesson Pipping and Eleanor Wikborg in Mandal and Southam, eds, The Reception of Jane Austen in Europe, 32, 121, 154.

37 Ebine, et al., "Jane Austen in Japanese Literature: An Overview".

38 See Section C. "Translations" in Gilson, A Bibliography of Jane Austen, 133-207.

39 The figures for European translations are my own calculations, based on the Timeline in Mandal and Southam, eds, The Reception of Jane Austen in Europe.

40 Zhang, “Jane Austen's One Hundred Years in China”, 110. 
the other four novels have had four translations each, which seems a sober estimate judging from his material, this means at least seventy-six Chinese Austen-titles. ${ }^{41}$

It is even more difficult to make a guess for Japanese, which has had repeated translations since 1926, and of all of Austen's work, juvenilia and letters included. ${ }^{42}$ Austen is seen to have influenced Japanese authors since novelist and scholar Natsume Sõseki took her as his model a hundred years ago, ${ }^{43}$ and Japan has had its own Jane Austen Society since 2006. Since there have been seventeen translations in circulation in recent years, it will be no exaggeration to assume there have been at least thirty in total. Likewise, information provided in two articles by Turkish scholars indicates that translations in that country must at least amount to twenty since $1946 .{ }^{44}$

So, although a total figure for translations is at present impossible, we can venture to state that Austen's work has been transmitted in more than 680 foreign versions, and predominantly since the 1920 s. They deserve serious study, and it is the extent of this largely unfamiliar landscape that also motivates the present book. There are large blank spots on the map of Austen's worldwide travels that need to be described by scholars of translation.

Although the mid-19gos represent a watershed in Austen's reception, her previous popularity must not be underestimated. As a small sample of Austen's status around the world also before the recent film waves, she was reported to be very popular in Poland around $1980 .{ }^{45}$ At the same time in India, the number of reprints and translations of her novels was evidence of Austen's great appeal to Indian readers. They seemed to appreciate her for her family values, which were seen to be similar to traditional Indian ones, as commented

41 Austen's popularity in China was noted already in a 1981 article headed "Chinese Buy Austen" from The New York Times, 3 January, 19. Pride and Prejudice was "among the most popular translations" of all (see Barry Roth, An Annotated Bibliography of Jane Austen Studies, 1973-83, Charlottesville, 1985, Item 519).

42 Ebine, et al., "Jane Austen in Japanese Literature: An Overview".

43 See also Miyuki Amano, "Sõseki's Transformation of the Austenian Novel: From the Novel of Manners to the Psychological Novel"; Kazuko Hisamori, "Elizabeth Bennet Turns Socialist: Nogami Yaeko's Machiko"; Hiroshi Ebine, "Experimenting with Jane Austen: Kurahashi Yumiko", all in Persuasions On-Line, 30/2.

44 Sebnem Toplu, “Love or Pride by Jane 'Austin'?: Jane Austen's Reception in Turkey", in Re-Drawing Austen: Picturesque Travels in Austenland, eds Beatrice Battaglia and Diego Saglia, Naples, 2004, 379-81; Tekcan, "Jane Austen in Turkey". The latter also includes illustrations of covers.

Roth, An Annotated Bibliography of Jane Austen Studies, 1973-83, Items 216 and 219. 
by Barry Roth, referring to Atma Ram, ${ }^{46}$ and a couple of decades later so vividly illustrated in Bollywood productions of the novels, such as Kandukondein Kandukondein (2000), Bride and Prejudice (2004), and Aisha (2010).

This leads to the following questions: when Austen is adopted into different countries of the world, what do they want from her? What kind of an author is she seen to be, what purpose do the translations serve and what readerships do they address? Clearly, not only one purpose or readership, but various, at different times and places, as can be guessed from a mere glance at the appearance of the books. Sometimes she comes out in leather bindings, in a decorative collection of classics, at other times she finds herself among railway station romances. The choice of translators is often indicative of her status. Is she tackled by the Shakespeare translators or by translators of entertainment literature? Is there a particular skill to reading and understanding Austen, or can any translator accomplish it?

Considering this question, we may argue that Austen is not as difficult as she is sometimes suspected to be by modern potential readers. In some ways, she cultivates clarity and simplicity of narrative and language. There are no lengthy essays on topical matters or philosophical issues, as in George Eliot's books, for instance. There is very rarely any argument carried out or points to be made. There is not even a particularly old-fashioned, intricate, and obscure language, considering that it is two hundred years old. Many of her contemporaries would give translators much more trouble in this respect. Translators do sometimes express anxiety about her antiquity, but this is hardly the main challenge of her narratives.

However, as scholars have already observed, Austen's stories do pose a major challenge in understanding and translating her consistent irony. It follows that translators who are not aware that the author's style reflects her attitude, will end up with a very different story, sometimes even the opposite of the original work in its tone and idea. This is what for instance Valérie Cossy has found in her analysis of Isabelle de Montolieu's versions of Sense and Sensibility and Persuasion. ${ }^{47}$ The coming chapters will provide many examples of Austen's style and tone in more or less felicitous renderings.

46 Roth refers to a now rare Indian publication, Atma Ram's Heroines in Jane Austen (1982), which apparently included a bibliography of Indian translations until then. See ibid., Item 610.

47 Valérie Cossy, Jane Austen in Switzerland: A Study of the Early French Translations, Geneva and Paris, 2006. By the same author, also "Austen and Her French Readers: Gender and Genre Again", in Re-Drawing Austen: Picturesque Travels in Austenland, eds Beatrice Battaglia and Diego Saglia, Naples, 2004, 349-50. 
These samples are very likely comparable to what can be found in the translations of other countries. This is why a study of Norwegian translations is relevant also for other parts of the worldwide Austen academia. The observations and conclusions drawn here will be seen to have a validity and interest that transcend the national. The methods and approach are to investigate general issues of literary translation, where Norwegian cases serve as illustrations. Moreover, judging from the few existing studies of Austen in translation, there are remarkable parallels between her reception in for instance Northern Europe and Eastern Asia. Likewise, when Helen Chambers, one of the few who attempts a similar method, delivers close readings of two German translations, she turns up several of the same problems as found in the Norwegian material. ${ }^{48}$ In order to get a better picture of Austen abroad, we need more studies undertaken by scholars that master the various target languages of Austen translated. Only then can we begin to understand Jane Austen's international influence, by means of such a joint transnational effort.

When present-day scholars do sometimes examine the global Jane Austen, it is often by means of comparisons with foreign authors, a description of tendencies and influences, and to a lesser extent accounts of the number of translations, or indeed a study of their qualities. ${ }^{49}$

"Studies of the translations and of Jane Austen's reception abroad have been few", Gilson remarked in $1997 .{ }^{50} \mathrm{Up}$ until then, there had been only two longer studies of translations: a Spanish doctoral dissertation comparing two Spanish versions of Persuasion in 1981, and an American one on the German reception in $1983 .{ }^{51}$ Since then there have been important contributions, not least on the eighteen countries represented in The Reception of Jane Austen in Europe,

48 Helen Chambers, "Nineteenth-century German Translations of Jane Austen", in Beiträge zur Rezeption der britischen und irischen Literatur des 19. Jahrhunderts im Deutschsprachigen Raum, ed. Norbert Bachleitner, Amsterdam and Atlanta, GA, 2000.

See for instance the Persuasions On-Line special issue on Global Jane Austen (28/2, 2008), which encompassed contributions from around the world on matters as different as Austen and The Arabian Nights, Japanese literature, Spanish and Indian film adaptations, but only one study of Austen in translation - into Turkish. See also the more recent anthology with the same title, which studies Austen's worldwide appeal, including how she is used in Indian and Chinese classrooms, but includes only one study of translations, into French (Global Jane Austen: Pleasure, Passion, and Possessiveness in the Jane Austen Community, eds Laurence Raw and Robert G. Dryden, New York and Basingstoke, 2013).

$5^{0}$ In his new Introduction to the 1997 reprint (Gilson, A Bibliography of Jane Austen, xxxiii).

51 Both listed in Roth, An Annotated Bibliography, 1985, Item 523. Barry Roth published three bibliographies, covering everything that was written about Austen in articles, books and dissertations between $195^{2}$ and 1994. 
first published in 2007. ${ }^{2}$ This is the main resource for anybody interested in Austen in translation. Besides, there have been two monographs on translations into French in France and Switzerland, respectively, ${ }^{53}$ and book chapters on Austen's reception in Germany, ${ }^{54}$ France, Italy, Russia and Turkey. ${ }^{55}$ Some articles on China, Japan and Turkey complement the picture. ${ }^{56}$

It is, however, still a neglected field of academic interest, pointed to in recent Austen research: "close analysis of the different translations constitutes a crucial area of Austen scholarship still largely neglected", Cossy and Saglia find. ${ }^{57}$ Gillian Dow states that "relatively few scholars have considered the 'foreign' or 'translated' Austen comprehensively, or in any depth".58

Such studies are perhaps rare because of the work they inevitably entail, aptly described by Lawrence Venuti as "the onerous task of examining translations against the source texts they translate". ${ }^{9}$ They may also be rare because they are (mistakenly) felt to be relevant only for the country or language in question, rather than forming part of a joint project. The present book is one small contribution towards such a larger collaborative effort.

The burgeoning concern for studying Austen-translations is related to a growing interest in the general field of translation over the last three decades.

52 The Reception of Jane Austen in Europe, 2007/2014, eds Mandal and Southam.

53 Lucile Trunel, Les editions françaises de Jane Austen, 1815-2007, Paris, 2010; Cossy, Jane Austen in Switzerland: A Study of the Early French Translations. See also Lucile Trunel, "Jane Austen's French Publications from 1815: A History of a Misunderstanding", in Global Jane Austen, eds Laurence Raw and Robert G. Dryden, New York and Basingstoke, 2013.

54 Chambers, "Nineteenth-century German Translations of Jane Austen".

55 Cossy, "Austen and Her French Readers: Gender and Genre Again"; Mirella Agorni and Elena di Giovanni, "Pride and Prejudice in Italy"; Gabriella Imposti, "The Reasons for an 'Absence': Jane Austen's Reception in Russia”; Toplu, “Love or Pride by Jane 'Austin'?: Jane Austen's Reception in Turkey", all in Re-Drawing Austen: Picturesque Travels in Austenland, eds Beatrice Battaglia and Diego Saglia, Naples, 2004.

$5^{6}$ Ebine, et al., "Jane Austen in Japanese Literature: An Overview"; Tekcan, "Jane Austen in Turkey”; Zhang, “Jane Austen's One Hundred Years in China”. See also Hiroko Furukawa's study of the feminizing of Austen's language by male Japanese translators in "Rendering Female Speech as a Male or a Female Translator: Constructed Femininity in the Japanese Translations of Pride and Prejudice and Bridget Jones's Diary", in Translation: Theory and Practice in Dialogue, eds Antoine Fawcett, Karla L. Guadarrama García and Rebecca Hyde Parker, London: Continuum, 2010, 181-98.

57 Valérie Cossy and Diego Saglia, “Translations”, in Jane Austen in Context, ed. Janet Todd, Cambridge, 2007, 169 .

$5^{8}$ Gillian Dow, “Uses of Translation: The Global Jane Austen”, in Uses of Austen:Jane's Afterlives, eds Gillian Dow and Clare Hanson, Basingstoke and New York, 2012, 158.

59 The Translation Studies Reader, ed. Lawrence Venuti, London and New York, 2012, 273. 
From being considered a mere auxiliary to the field of linguistics, translation studies have been established as an independent academic discipline, particularly since the 1980s. One watershed was the publication of Susan Bassnett's Translation Studies (1980), which did much to secure translations the status of creative texts in their own right. For the fourth edition of 2014, Bassnett comments that "Today ... interest in the field has never been stronger".60

As a meeting-ground for the traditional disciplines of foreign-language study (literature, culture, linguistics) the field today is marked by a plurality of approaches, methods and theories. One such development over the last four decades is the greater focus on the receiver of translation: the reader and the target culture. Itamar Even-Zohar is one of the scholars who pointed out the undervalued position translations have had. His theory provided a place for translation as a distinct (and "most active") system within the literary "polysystem", and also explained how small, peripheral cultures had more need for translation than larger, more central ones. ${ }^{61}$

As a peripheral country with long traditions for importing the literature of Germany, France and Britain, the Norwegian fondness for translation serves as a case in point. Even-Zohar's call for studies of the functions of translations in literary history also motivates the present study. Which authors and texts are selected for translation at different times, and how do translations adapt the source text to the codes of the receiving culture? More specifically, what uses has Jane Austen been put to?

The emphasis on receivers is closely connected with the hermeneutic perspective on texts: that they are always interpreted differently by different readers. The interest in finding out how readers understand, based on their own contexts (or horizons), is a main concern in studying how translators render Jane Austen's novels. A significant voice in post-war hermeneutic philosophy, inspiring such fathers of reception studies as Wolfgang Iser and Hans-Robert Jauss, is Hans-Georg Gadamer. In his seminal Truth and Method (1960), he discusses the processes of interpretation, stressing both the limitations of any one interpreter, and the endless possibilities of meaning in any text. ${ }^{62}$ This forms the foundation for describing (in the present material) seven such interpreters coming up with different results when faced with Jane Austen's novels.

Among recent scholars who bring a hermeneutic approach to the study of translation, Lawrence Venuti's theoretical stance will be considered below,

\footnotetext{
6o Bassnett, Translation Studies, 2.

61 See Itamar Even-Zohar, "The Position of Translated Literature within the Literary Polysystem", in The Translation Studies Reader, ed. Venuti, 162-67.

62 Hans-Georg Gadamer, Truth and Method, London, 1989, 373.
} 
for instance in Chapter 9: "Foreign or Domestic?" He has contributed a critical perspective on a translation practice that assimilates texts into the target culture to the extent of eradicating the foreign, and argued for a more visible, overt role for the translator. His prescription of "how to read a translation" is illuminating: "not as a simple communication of a foreign text, but as an interpretation that imitates yet varies foreign textual features in accordance with the translator's cultural situation and historical moment".63 This is exactly what Gadamer expressed in his focus on the interpreter's historical horizon of interpretation.

The hermeneutic emphasis resulted in a preference for more descriptive, less evaluative approaches to the study of translations. Rather than count and list all losses in a given translation when compared to its source, there was more interest in seeing the translator as a creative artist producing his/her own version in an ongoing dialogue between texts. ${ }^{64}$

In such a theoretical climate, is there a room for comparative analysis of translation, such as proposed in the present book? More than carving out a space for comparison, it is in a sense, unavoidable, or even the core of translation studies. The concept of translation describes the relationship between (at least) two texts. If maintaining that the new text is an entirely independent work of art, it is no longer possible to do a translation study. At the heart of translation studies is the question of what happens in the transfer of texts between languages. In order to find out how literary texts are understood by readers at different times, a comparison between original and translation is implied. 65

Furthermore, there is the need for comparisons between different translations of the same literary work. For many of the best-known authors there are multiple translations, even into minor languages. In addition to relating to the source text, these translators will also often relate to the versions of their predecessors, sometimes depending on them, at other times positioning themselves as alternatives. ${ }^{66}$

63 Lawrence Venuti, The Translator's Invisibility: A History of Translation, London and New York, 2008, 124.

64 See description of the post-colonial approach in Bassnett, Translation Studies, 7.

65 I find confirmation of this point in Susan Bassnett's observation that "there is always a comparative element", ibid., 12. See also "The Value of Comparing Translations", in Susan Bassnett, Reflections on Translation, Bristol, Buffalo, Toronto, 2011, 126.

66 See Merete Alfsen's postscript to her series of Austen translations, commenting on the liberal editing practices of earlier times (Alfsen, "Oversetterens etterord", Stolthet og fordom, Oslo: Aschehoug, 2003, 363). 
For an analysis of the reception of an author in a particular language and culture, it is therefore useful to see how the different versions communicate with each other as well as with their source text. It is also of the utmost interest to see whether translators read Shakespeare or Austen differently over time, and which aspects of their work are wanted or discarded.

A third level of comparison depends on the co-operation between scholars in different countries. The more studies appear of translations into different languages, the better the afterlife of an author can be described. Such a further step can be taken when there are available studies (in English) of the translations of, say, Dickens or Woolf into a number of languages. This is the motive for providing such a study of Jane Austen into Norwegian.

Jane Austen is travelling extensively across the globe. This book will focus on one little corner of the world of Austen readers, on one language community, to enable a study of what happens when Austen's language and style are translated into a foreign language. We may hope that in the future more such studies for other languages will give us better understanding of the possibilities and limitations of translating Austen's authorship, as well as of the diverse images of Austen abroad.

The following chapters can be read without any knowledge of Norwegian, as all quotations are back-translated. Chapter 1 will give a chronological overview of all Norwegian translations, with an assessment of their main characteristics, and also include some information about what place the translators had in the literary world. Chapters 2 to 12, rather than focusing on single translations, will focus on common features, such as deletions, repetitions, archaizing or censorship. Through comparing seven different translators, patterns will arise that will be recognizable and valid in other countries as well. In this way, I hope that this map of Norwegian translations can take its place in the travelogue of Jane Austen's worldwide expansion. 


\section{Morgenbladet.}

So. $361 \mathrm{~B}$.

Gontag D. 31: Dectuber 1871.

53: ชare.

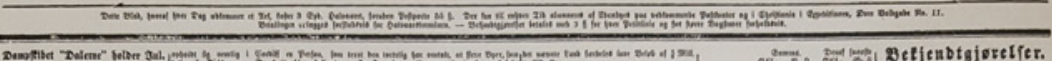

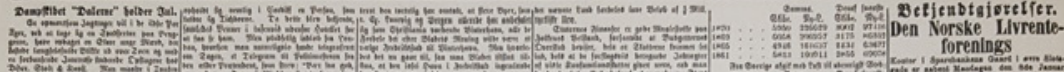

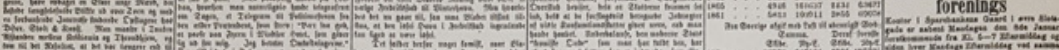

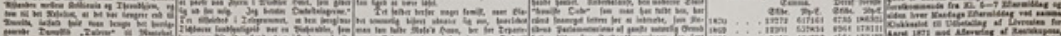

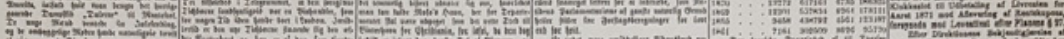

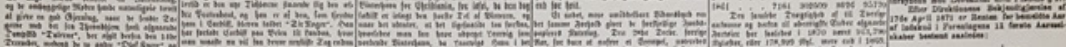

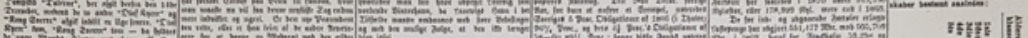

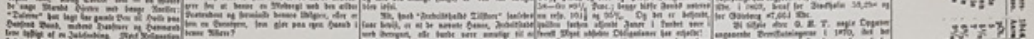

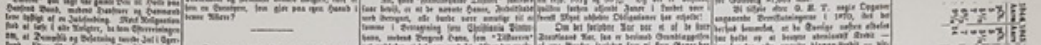
E

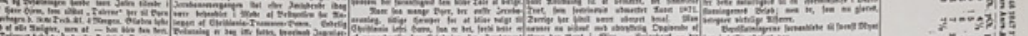

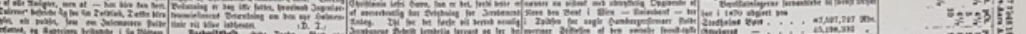

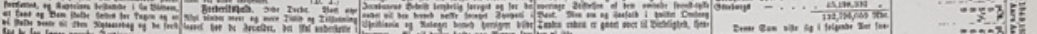
a k

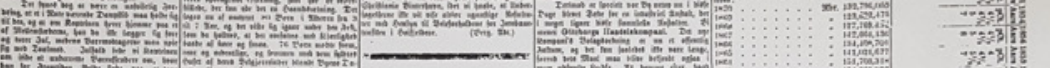

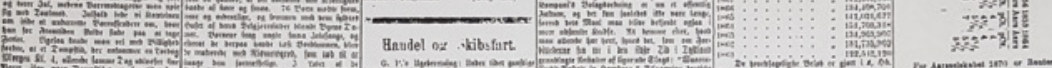

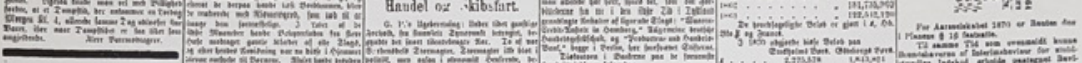

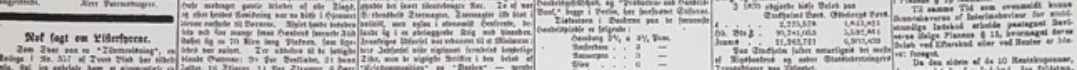

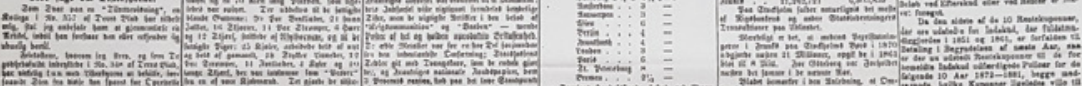

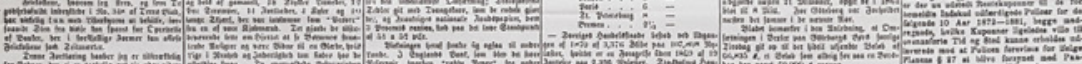

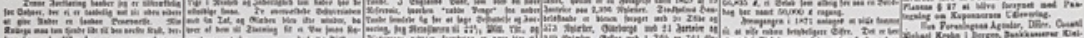

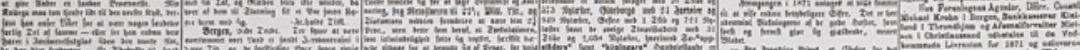

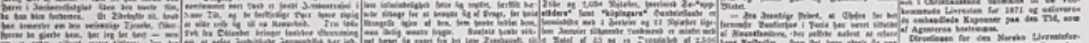
EN Firger

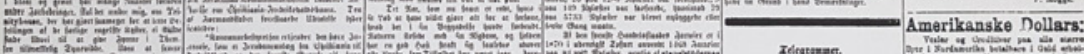

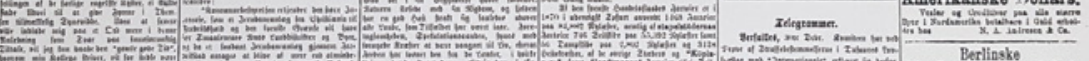

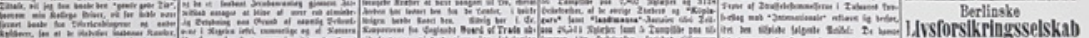

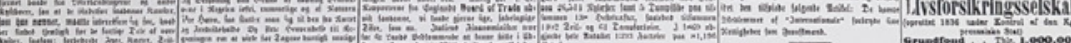

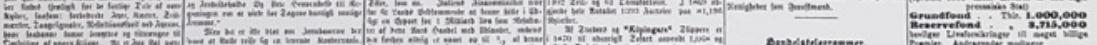
50.

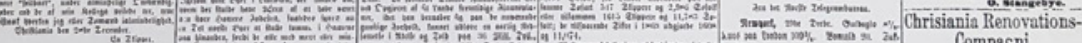

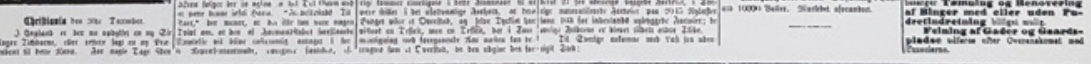

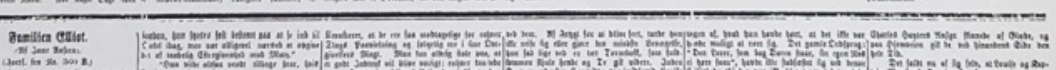
rom

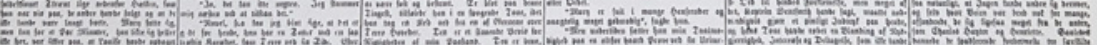

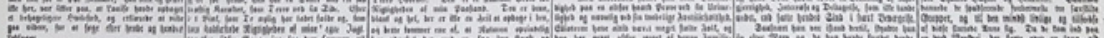

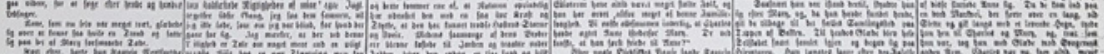

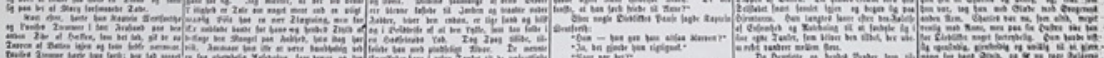

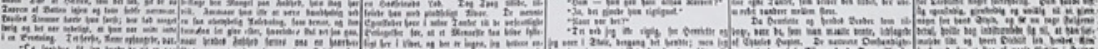

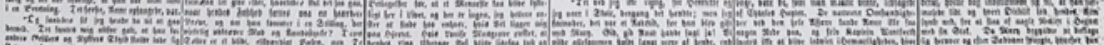

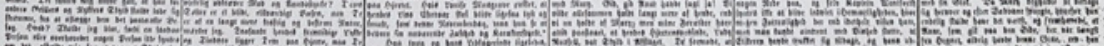

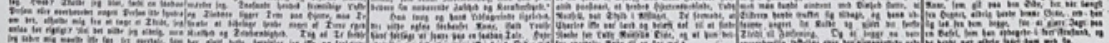
-

From late December 1871 through January 1872 the newspaper Morgenbladet ran a serialized translation of Persuasion, printed across the bottom of the two first pages. 


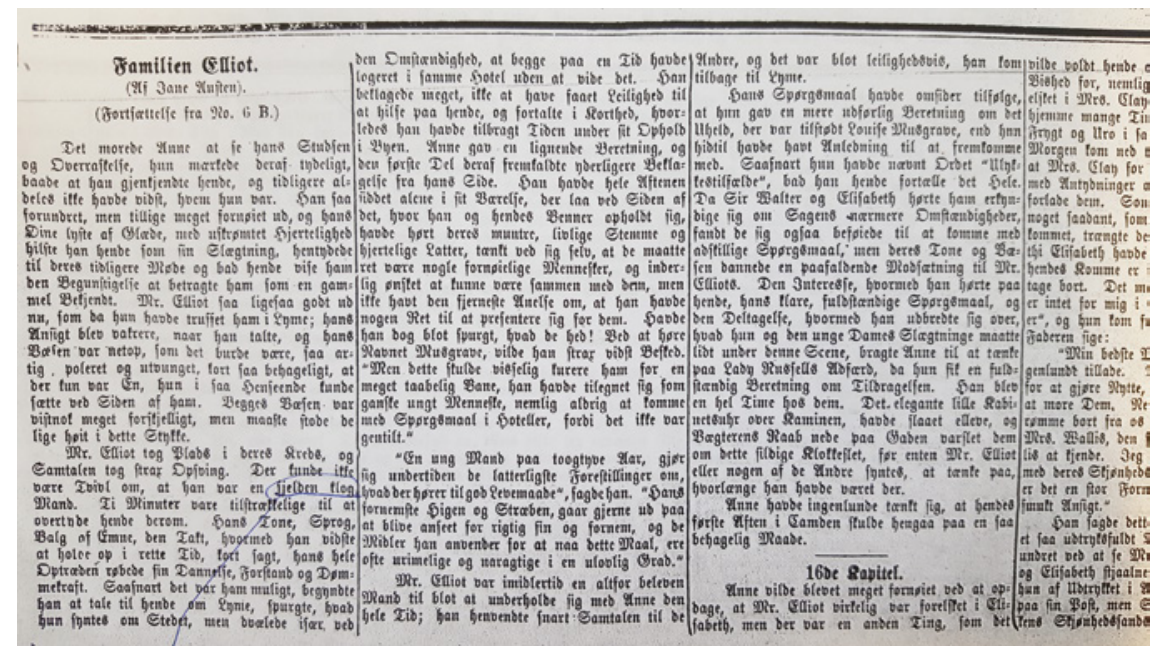

FIGURE 2 Chapter 15 of Persuasion in Norwegian translation and Gothic typeface. 